\title{
Effect of the spontaneous fermentation and the ageing on the chemo-sensory quality of Brazilian organic cachaça
}

\author{
Efeito da fermentação natural e do envelhecimento sobre a qualidade química e sensorial de cachaça \\ orgânica Brasileira
}

\author{
Afra Vital Matos Dias Gabriel ${ }^{\mathrm{I}, \mathrm{II}}$ Marta Regina Verruma-Bernardi ${ }^{\mathrm{II}}$ Luiz Antônio Corrêa Margarido ${ }^{\mathrm{II}}$ \\ Maria Teresa Mendes Ribeiro Borges ${ }^{\text {II }}$ Renata Tieko Nassu ${ }^{\text {III }}$ Norberto Antonio Lavorenti ${ }^{\text {II }}$ \\ Sandra Regina Ceccato-Antonini ${ }^{\mathrm{I}, \mathrm{II}^{*}}$
}

\section{ABSTRACT}

This study verified the effect of the spontaneous fermentation/natural ferment (NF) on the chemo-sensory quality of cachaça, comparing to the commercial ferment (CF). The effect of ageing (maturation) was also analysed in the beverage. Microbiological analysis (plating on selective media for total/wild yeast and bacteria counting) and physicochemical analysis ( $\mathrm{pH}$, acidity and soluble solids) were performed in the samples of the must and the ferment collected during three cycles of fermentation in a semi-industrial scale. Samples of cachaça were stored in 5-L oak containers for 45 days, subsequently analyzing the physico-chemical characteristics ( $\mathrm{pH}$, acidity, alcohol content, copper and secondary compounds) and sensory acceptability (aroma, flavour, colour, body and global impression). The fermentation with NF showed higher number of wild yeasts; however there was no difference in the number of bacteria comparing to CF. An intense acidification occurred during the preparation of NF, which was also observed in the initial cycles of fermentation, but decreased afterwards. Greater alterations in cachaça composition were found to be more exclusively related to the maturation than to the type of ferment, except for the acidity. However, there was a significant loss of aroma, flavour and global impression after maturation but only in cachaça produced with the CF. The results revealed a strong interaction between ferment and maturation of the beverage, suggesting that substances produced by the microorganisms from different inocula during fermentation reacted differently with the wood components of the barrels influencing the sensory attributes.

Key words: alcoholic beverage, sensorial quality, physicochemical quality.

\section{RESUMO}

Este trabalho teve por objetivo avaliar o efeito da fermentação espontânea/fermento natural (NF) sobre a qualidade fisico-química e aceitabilidade da cachaça, comparando-se com o fermento comercial (CF). O efeito do envelhecimento (maturação) da bebida foi também avaliado. Análises microbiológicas (plaqueamento em meios seletivos para contagem de leveduras totais/selvagens e bactérias) $e$ físico-químicas ( $\mathrm{pH}$, acidez e sólidos solúveis) foram conduzidas nas amostras do mosto e do fermento coletadas durante três ciclos fermentativos (escala semi-industrial). Amostras de cachaça foram armazenadas em barris de carvalho de 5 litros por 45 dias, seguindo-se a análise físico-química ( $p H$, acidez, teor alcoolico, cobre e compostos secundários) e de aceitabilidade sensorial (aroma, sabor, cor, corpo e impressão global). A fermentação com NF mostrou maior número de leveduras selvagens; no entanto, não houve diferença significativa no número de bactérias quando comparada com CF. Uma intensa acidificação foi observada durante o preparo de NF, a qual foi verificada nos ciclos iniciais da fermentação, decrescendo a seguir. As alterações na composição da cachaça foram mais significativas em relação à maturação do que ao tipo de fermento, com exceção da acidez. No entanto, houve uma perda significativa de aroma, sabor e impressão global após a maturação na cachaça produzida com CF. Os resultados revelaram uma forte interação entre fermento e envelhecimento (maturação) da bebida, sugerindo que substâncias produzidas pelos microrganismos a partir de inóculos diferentes reagiram diferentemente com componentes da madeira dos barris, influenciando nos atributos sensoriais de aceitabilidade.

Palavras-chave: bebida alcoolica, qualidade sensorial, qualidade físico-quimica, fermento.

\footnotetext{
'Programa de Pós-graduação em Agroecologia e Desenvolvimento Rural, Universidade Federal de São Carlos (UFSCar), Campus de Araras, Araras, SP, Brasil.

IIDepartamento de Tecnologia Agroindustrial e Socioeconomia Rural, UFSCar, Campus de Araras, 13600-970, Araras, SP, Brasil. E-mail: antonini@cca.ufscar.br.*Autor para correspondência.

IIIEmbrapa Pecuária Sudeste, São Carlos, SP, Brasil.
} 


\section{INTRODUCTION}

Around $30 \%$ of the annual production in Brazil, which is estimated to be 1.3 billion litres, constitutes the artisanal cachaça, in which the fermentation is initiated by autochthonous yeasts from the sugar cane juice, the so-called natural ferment (PATARO et al., 2000). The preparation of this traditional starter ferment does not follow a standard recipe and basically consists of adding sugar cane juice to crushed corn and powdered rice (ROSA et al., 2009). It is a spontaneous fermentation using wild yeasts (nonSaccharomyces) and Saccharomyces cerevisiae, with a predominance of the latter species (MORAIS et al., 1997; PATARO et al., 1998). As a consequence, artisanal cachaças have different sensory qualities due to the metabolites and volatiles produced by the diversity of yeasts present during the fermentation process. Hence yeast composition is a key factor in cachaça quality (NOVA et al., 2009). Non-Saccharomyces yeasts studied by OLIVEIRA et al. (2005) in small-scale sugar cane fermentations did not exert a negative influence on the sensory quality of the cachaça. Wild yeasts (Pichia silvicola, Pichia anomala and Dekkera bruxellensis) were also adequate for high-quality cachaça production, because these microorganisms produce acceptable concentrations of secondary compounds (DATO et al., 2005).

Studies on the chemo-sensory quality of artisanal organic cachaça produced with natural ferment are scarce. Besides, although the ageing is optional for cachaça, it is a common technique for distilled beverages in several countries resulting in a better sensory quality, and constitutes the final step in the production of distilled beverages of differing qualities (FARIA et al., 2003). In this context, this work aimed to evaluate the influence of the spontaneous fermentation on the chemo-sensory characteristics of artisanal organic cachaça, comparing to the commercial ferment. The effect of maturation (ageing) in oak barrels was also evaluated, as a contribution to those small producers who want to create a different quality beverage.

\section{MATERIAL AND METHODS}

Initially the natural yeast inoculum (NF) was prepared by mixing $2 \mathrm{~kg}$ rice bran, $1 \mathrm{~kg}$ breadcrumbs and $1 \mathrm{~kg}$ corn flour, which were enclosed in a cotton tissue into a container with around 30L of diluted sugar cane juice $\left(6-7^{\circ} \mathrm{Brix}\right)$ and then heated at $28^{\circ} \mathrm{C}-35^{\circ} \mathrm{C}$. Five additions of $15 \mathrm{~L}$ of diluted sugar cane juice were made within a 10-day period until a volume of approximately 100L was obtained to be added to the fermentation tanks. The juice was extracted from the sugar cane variety RB855156 cultivated under organic management in Araras, São Paulo State, Brazil. The harvest was made manually without burning and the sugar cane stalks were crushed on the day of harvesting.

The fermentations were carried out in four 1000-L tanks (200-L working volume), two for each ferment (NF; and CF as fresh baking yeast Fleishmann ${ }^{\circledR}$ in the proportion of $8 \mathrm{~g} \mathrm{~L}^{-1}$ hydrated in warm water before inoculation in the tank), in a cell-recycle process for three consecutive cycles, at room temperature $\left(30^{\circ} \mathrm{C}\right.$ $32^{\circ} \mathrm{C}$ ). The initial cell concentration was $10^{6}-10^{7}$ living cells $\mathrm{mL}^{-1}$ for both inocula. After the fermentation completion, the must was distilled and around $20 \%$ vol $\mathrm{vol}^{-1}$ of the ferment remained in the tank for the next cycle.

The distillation (150-200L of fermented must) was conducted in 300-litre copper alembics with pre-heater and cooler, discarding the "head" and "tail" fractions (around $10 \%$ of the initial and final distillate, respectively). The "heart" fraction was diluted in distilled water and distilled again according to FRANCO (2008). The distilled samples were separated in "head", "tail" and "heart" fractions again and the last fraction was kept in glass containers for chemosensory analysis (at $40^{\circ} \mathrm{GL}$ ) and stored (at $42^{\circ} \mathrm{GL}$ ) in 5litre oak barrels for 45 days, based on the work of BORRAGINI (2009).

Cachaça samples (at $42^{\circ} \mathrm{GL}$ ) were analysed for copper, with direct measuring by atomic absorption spectrometry - Perkin-Elmer 373 (AOAC, 1995); acetaldehyde, ethyl acetate, methanol, n-propanol, isobutanol and isoamyl alcohol, using gas chromatography with a flame ionization detector (INSTITUTO ADOLFO LUTZ, 1985); pH, with direct measuring in a digital $\mathrm{pH}$-meter; alcohol content $\left({ }^{\circ} \mathrm{GL}\right)$, using a digital densimeter; total, fixed and volatile acidity, by titration (AMORIM et al., 1979). The concentration of higher alcohols (sum of n-propanol, isoamyl alcohol and isobutanol) and total volatile compounds (sum of volatile acidity, higher alcohols, acetaldehyde and ethyl acetate) were estimated. Samples of the natural ferment (during preparation), must (at the start of the fermentative cycle) and ferment were taken out and analysed for $\mathrm{pH}$ and total acidity; and soluble solids ( $\left.{ }^{\circ} \mathrm{Brix}\right)$, using a refratometer. For microbiological analysis, samples of the must and ferment were centrifuged at 3,000rpm for 5 minutes, and the washed supernatant was serially diluted and plated onto WLN, WLD and Lysine Agar for yeast and Nutrient Agar for bacteria countings (CECCATOANTONINI, 2010). The plates were incubated at $30^{\circ} \mathrm{C}$ for 2 and 3 days (for bacteria and yeasts, respectively).

For the sensory analysis of acceptability (affective test), a panel of 62 non-trained judges 
evaluated the samples with respect to aroma, flavour, colour, body (adstringency) and global impression, using a 7-point hedonic scale ranging from "dislike very much" to "like very much". The cachaça samples $(20 \mathrm{~mL})$ were served in transparent, colourless containers labelled with a three-digit code and presented in a monadic manner (MacFIE et al., 1989). White light was used in the individual booths, with a balanced presentation of the cachaça samples according to a completely randomized block design. The sensory tests were approved by the University Ethics Committee (CAAE 0026.0.135.000-09).

The analysis of variance and Tukey's test $(\mathrm{P}<0.05)$ were utilized for the comparisons but for the sensory analysis data the non-parametric test of Kruskall-Wallis was employed.

\section{RESULTS AND DISCUSSION}

During the ferment preparation, the soluble solids values were kept constant due to the periodical addition of sugar cane juice; in contrast, the total acidity increased significantly probably due to the organic acid production, but without a relevant decrease in $\mathrm{pH}$ after 2 days of preparation. A progressive increase in the total yeast count (from WLN medium), a stable number of wild yeasts resistant to actidione (from WLD medium) and a low number of non-Saccharomyces (from Lysine Agar) demonstrated that the number of Saccharomyces increased considerably with the addition of sugar cane juice (Figure 1). The yeast count increased 5 log cycles in a 10-day period, suggesting that a yeast selection occurred during the preparation of the NF, especially Saccharomyces, which are more adapted to the high sugar concentrations from the sugar cane juice. The high must acidification and alcohol content also contribute to the selection of yeasts that prevail in the cachaça production (MORAIS et al., 1997; PATARO et al., 2000). The high number of bacteria at the end of the preparation would be a negative point for the NF, but the microbiological analysis of the must and the ferment inside the fermentation tank in the first fermentative cycle showed bacterial count much lower than that observed in the $\mathrm{NF}$ at the end of preparation. A dilution effect by the introduction of the ferment into the tank or bacterial death caused by the high sugar concentration could explain this fact. Moreover, the NF does not constitute a primary source of bacterial contamination (Figure 1).

The microbiological analysis of the ferment after the fermentative cycles revealed that a higher number of yeasts was found in the CF, but for both ferments there was a decrease along the cycles. The number of wild yeasts leaned to decrease along the fermentative cycles with the NF while for the CF an increase or stabilization was verified (Figure 2). The characteristic nature of the ferments could explain these results once in the $\mathrm{CF}$ the yeast population is exclusively S. cerevisiae, but with the cell recycle and new sugar cane juice being introduced into the tanks, the ferment is contaminated with indigenous yeasts. With the NF, although these facts had also occurred, the yeast population is more stabilized because there was a previous adaptation and selection during the propagation of it. Thus the NF would be more refractory to the contamination by wild yeasts. The NF acidity was significantly higher and the residual solids (Brix) for both ferments were very low, as expected (Figure 3).

The NF-must presented a higher number of wild yeasts while there was no difference in the total number of yeasts and bacteria comparing to the CFmust (Figure 2). The values of $\mathrm{pH}$ were significantly lower in the NF-must but despite of the high total acidity in this initial inoculum, the values decreased significantly for both ferments during the fermentation. The soluble solids values in the CF-must was higher, however there was only significant difference in the last cycle (Figure 3).

The results of the chemical analysis for the redistilled cachaça are shown in table 1 . The cachaça pH differed significantly only in response to maturation, with significant decrease in values as already observed (PARAZZI et al., 2008). There were no significant variations in the copper values and they did not exceed the limit of $5 \mathrm{mg} \mathrm{L}^{-1}$ (CARDOSO et al., 2003), which was due to the redistillation (values decreased from 6.5 to $0.4 \mathrm{mg} \mathrm{L}^{-1}$ ). Maturation was found to have a significant impact on the total and fixed acidity, causing a 3-fold increase in total acidity. After maturation, the volatile acidity increased with the CF, while the fixed acidity was significantly higher with the NF. The influence of the yeast composition (ferment) on the cachaça quality was evident, but depended on the maturation of the beverage in oak barrels. The alcohol content and methanol level of the beverage remained within the limits of Brazilian laws (BRASIL, 2005). Neither the ferment nor the maturation influenced the concentration of methanol, ethyl acetate and isoamyl alcohol in the cachaças. The concentrations of n-propanol and isobutanol, and consequently of higher alcohols, were significantly enhanced by the maturation, but not differ regarding the ferment, except for the total volatile compounds, whose concentration increased significantly in the cachaça produced with the NF after maturation.

It seemed that the choice for a natural or a commercial ferment does not impact considerably the fermentation parameters and consequently the 


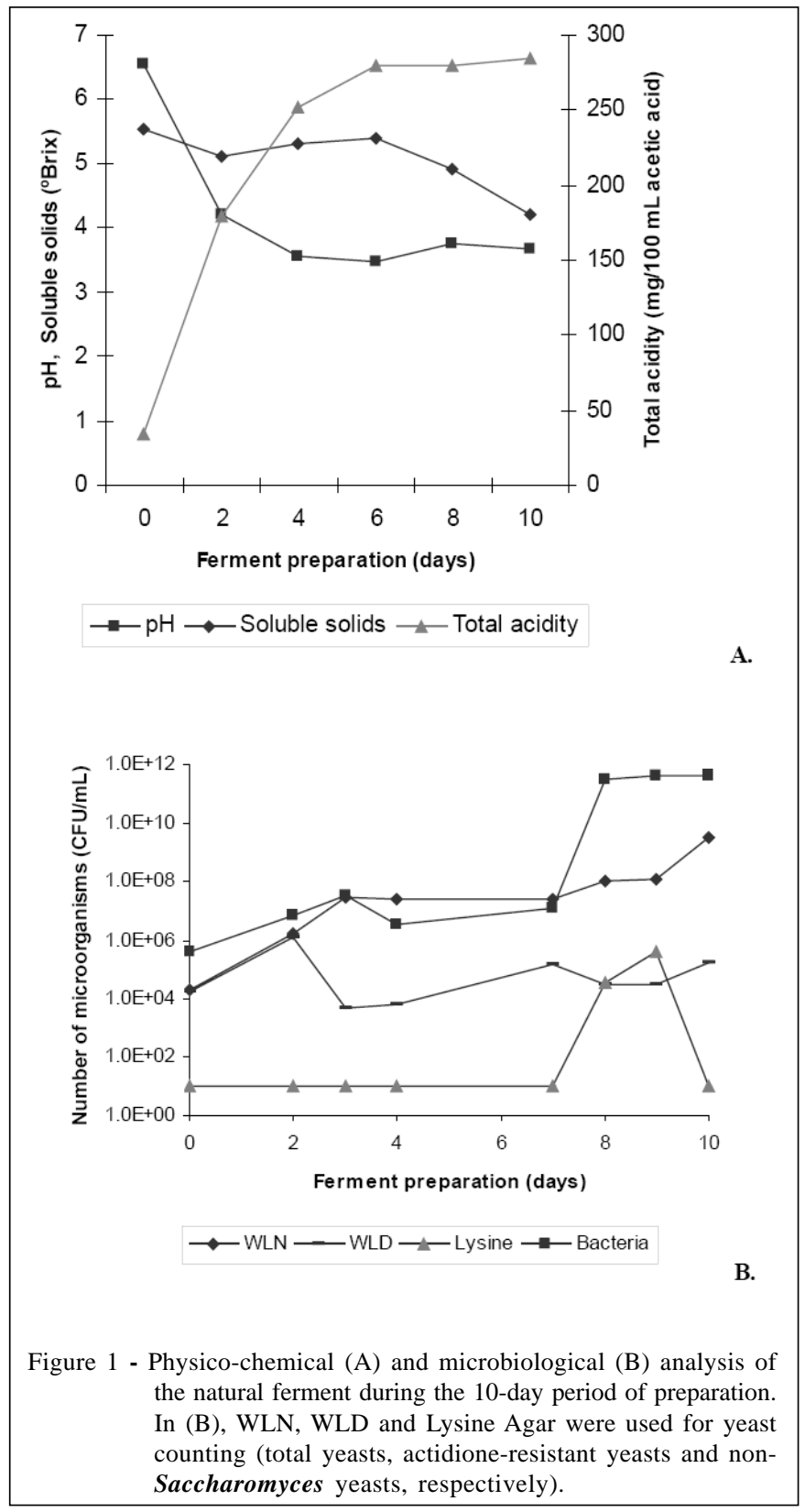

physico-chemical composition of the cachaça significantly, although more wild yeasts were found when natural ferment was utilized. Greater alterations in the cachaça composition were found to be more exclusively related to the maturation period inside the oak barrels. However, considering that cachaça is a beverage and for this reason, the sensory characteristics are also relevant, the evaluation of what extension the utilization of natural ferment alters these characteristics is crucial.

There was a significant loss of aroma, flavour and global impression after maturation but only in cachaça produced with the CF. Maybe an extensive scanning of compounds (other than those established by Brazilian legislation) produced by the microorganisms could help to substantiate this result, once the ageing (maturation) commonly brings about an increase in the sensorial quality of the beverages. For colour, there was a pronounced (and negative) effect of the maturation regardless the ferment, which is probably explained by the fact that the cachaça gets coloured (brownish colour) due to the interaction with the barrel wood, which may impress the judges used to prove uncoloured (not aged) cachaça (Table 2). The 


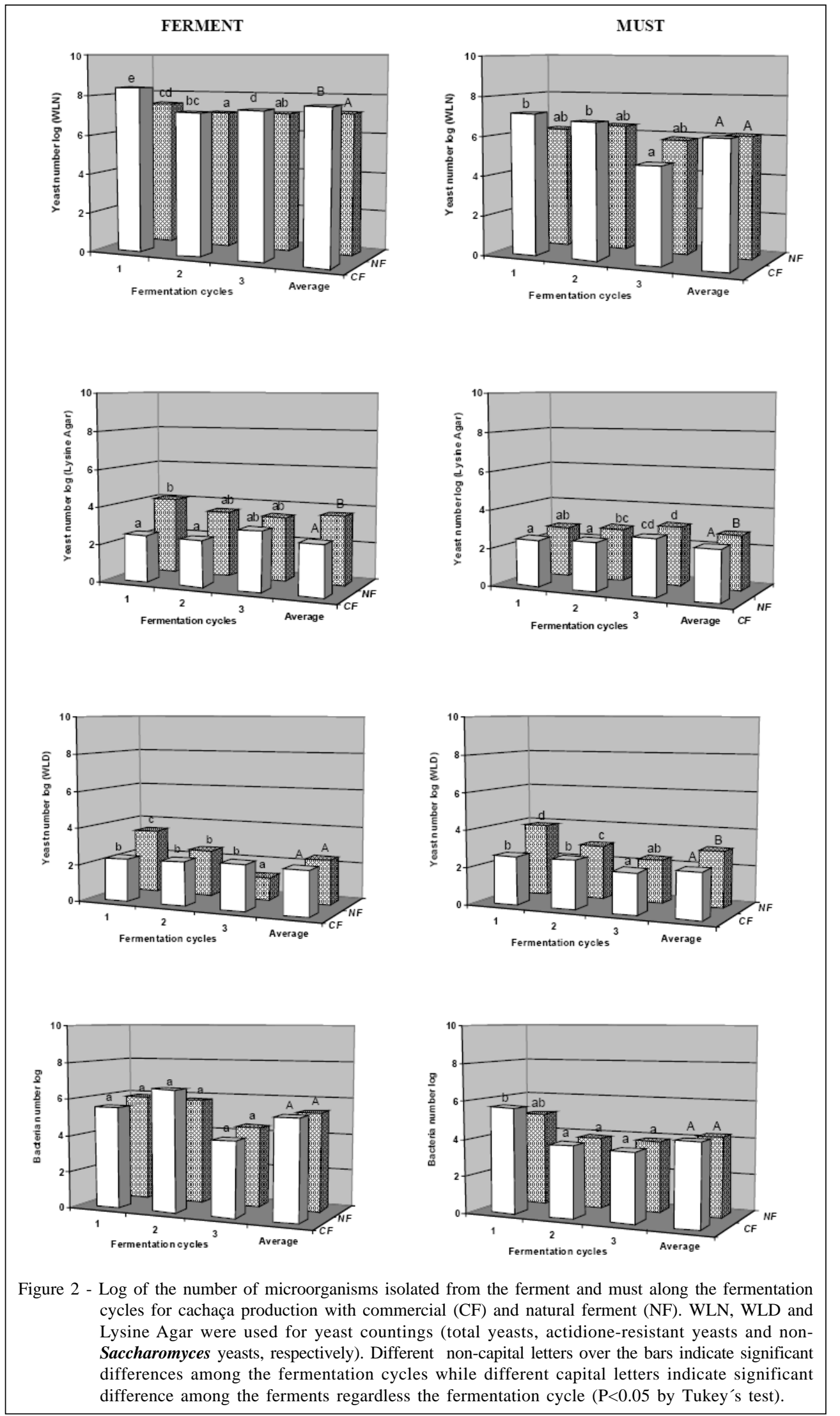

Ciência Rural, v.42, n.5, mai, 2012. 


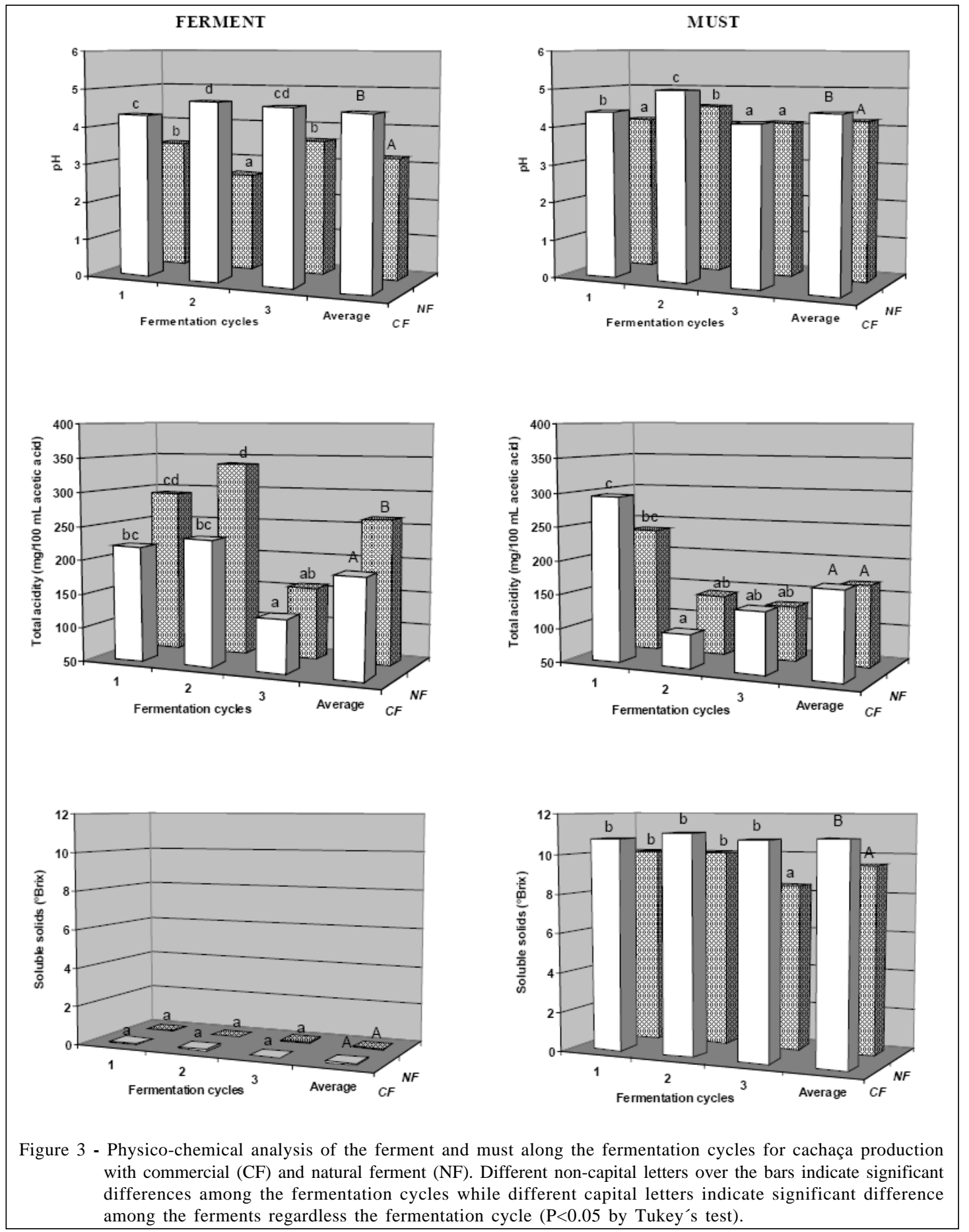

results revealed a strong interaction between ferment and ageing (maturation) of the beverage, suggesting that unknown substances produced by the microorganisms from different inocula during fermentation reacted differently with the components of wood barrels influencing the sensory attributes. Studies have demonstrated that cachaças produced by starter strains of $\boldsymbol{S}$. cerevisiae isolated as indigenous cultures from natural fermentations and from distillery received better sensorial evaluations (SILVA et al., 2009a, b).

A point to be considered is regarding the volume of barrels and time of ageing in the present work. The ideal time for the cachaça storage varies according to the barrel characteristics (type of wood, 
Table 1 - Chemical analysis of cachaças produced with commercial and natural ferments.

\begin{tabular}{|c|c|c|c|c|}
\hline \multirow{2}{*}{ Parameter } & \multicolumn{2}{|c|}{ 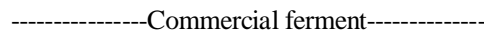 } & \multicolumn{2}{|c|}{------------Natural ferment--- } \\
\hline & Non-aged & Aged & Non-aged & Aged \\
\hline Fixed acidity ${ }^{1}$ & $1.14 \mathrm{a}$ & $6.76 \mathrm{~b}$ & $1.13 \mathrm{a}$ & $9.39 c$ \\
\hline Volatile acidity $^{1}$ & $3.29 \mathrm{a}$ & $4.89 \mathrm{~b}$ & $3.27 \mathrm{a}$ & 3.63ab \\
\hline Total acidity $^{1}$ & $4.43 a$ & $11.65 b$ & $4.40 \mathrm{a}$ & $13.02 \mathrm{~b}$ \\
\hline $\mathrm{pH}$ & $6.44 b$ & $4.70 \mathrm{a}$ & $6.92 b$ & $4.27 \mathrm{a}$ \\
\hline Alcohol ( $\left.{ }^{\circ} \mathrm{GL}\right)$ & $42.0 \mathrm{a}$ & $40.2 \mathrm{~b}$ & $42.0 \mathrm{a}$ & $40.5 \mathrm{ab}$ \\
\hline Copper $^{2}$ & $0.39 \mathrm{a}$ & $0.31 \mathrm{a}$ & $0.44 \mathrm{a}$ & $0.37 \mathrm{a}$ \\
\hline Acetaldehyde $^{2}$ & $6.42 \mathrm{ab}$ & $10.02 b$ & $5.62 \mathrm{a}$ & $8.85 a b$ \\
\hline Methanol $^{2}$ & $9.31 \mathrm{a}$ & $10.70 \mathrm{a}$ & $8.50 \mathrm{a}$ & $10.23 a$ \\
\hline Ethyl acetate ${ }^{2}$ & $8.35 \mathrm{a}$ & $10.63 a$ & $6.34 \mathrm{a}$ & $8.84 a$ \\
\hline N-propanol ${ }^{2}$ & $40.58 \mathrm{a}$ & $50.99 b$ & $37.64 a$ & $49.35 b$ \\
\hline Isobutanol $^{2}$ & $45.50 \mathrm{a}$ & $50.52 b$ & $36.26 a$ & $48.92 b$ \\
\hline Isoamyl alcohol $^{2}$ & $131.01 \mathrm{a}$ & $145.60 \mathrm{a}$ & 120.83a & $134.68 \mathrm{a}$ \\
\hline Higher alcohols ${ }^{2}$ & $217.08 \mathrm{a}$ & $247.11 b$ & 194.73a & $232.95 b$ \\
\hline Total volatile compounds ${ }^{2}$ & 235.13ab & $272.65 b$ & 209.97a & $254.27 \mathrm{~b}$ \\
\hline
\end{tabular}

Different letters in the lines indicate significant difference ( $\mathrm{P}<0.05$ by Tukey's test).

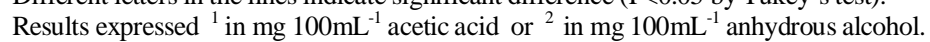

age and size) and to the environmental conditions of storage (temperature and moisture). Volumetric reductions may occur during the ageing process and the greater the barrel, the lower the loss by evaporation. It is also assumed that the shorter the barrel, the best is the extraction of the substances from the wood because of the closer contact of the beverage and the wood (higher specific surface). To avoid excessive volume reduction in the 5-litre barrel, a period of 45 days was here considered for ageing, best named as maturation. BORRAGINI (2009) has showed an increase in secondary compounds and acidity with longer time of ageing however the sensory quality of the cachaça did not differ substantially at 30 or 60 days of ageing in 5litre barrels comparing to longer periods until 180 days for the majority of the attributes.
A profound investigation on the chemical composition of cachaças besides the parameters considered in the legislation could substantiate the reason why the cachaça maturation may result in a different product depending on the type of inocula, because many unknown compounds should have been produced by the diversity of microorganisms, especially when NF is used. Although lack of control and homogeneity in the preparation can negatively impact this kind of ferment (natural), the results found in this study and others should not be ignored. Technological strategies to support and qualify the cachaça producers are required if this important agro-industry is to be stimulated and extended, ensuring the competitiveness and survival of small agricultural producers.

Table 2 -Averages and ranks of sensory acceptability for aged and non-aged cachaça, produced with natural ferment and commercial ferment.

\begin{tabular}{|c|c|c|c|c|c|c|c|c|}
\hline \multirow{3}{*}{$\begin{array}{l}\text { Attribute } \\
\text { Colour }\end{array}$} & \multicolumn{4}{|c|}{-------------Commercial ferment--------------- } & \multicolumn{4}{|c|}{ 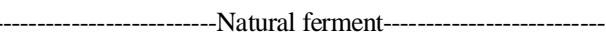 } \\
\hline & \multicolumn{2}{|c|}{--------Non-aged-------- } & \multicolumn{2}{|c|}{-----------Aged---------- } & \multicolumn{2}{|c|}{--------Non-aged---------- } & \multicolumn{2}{|c|}{-----------Aged-----------' } \\
\hline & 5.66 & $818.02 \mathrm{a}$ & 5.16 & $653.77 \mathrm{~b}$ & 5.62 & $807.80 a$ & 5.29 & 698.41b \\
\hline Aroma & 5.36 & $798.74 a$ & 4.91 & 669.71b & 5.36 & $766.34 a$ & 5.29 & $743.20 \mathrm{ab}$ \\
\hline Flavour & 4.62 & $802.45 a$ & 4.06 & $662.89 b$ & 4.53 & 786.49a & 4.31 & 726.17ab \\
\hline Body & 4.77 & 763.31a & 4.47 & $692.67 a$ & 4.76 & $762.95 a$ & 4.72 & 759.07a \\
\hline Global impression & 4.82 & 783.99a & 4.31 & $652.31 b$ & 4.77 & $780.50 a$ & 4.69 & 761.21a \\
\hline
\end{tabular}

Different letters in the lines for ranks indicate significant difference $(\mathrm{P}<0.05$ by Kruskall-Wallis non-parametric test); $\mathrm{n}=62$ judges (1="dislike much" to 7="like much").

Ciência Rural, v.42, n.5, mai, 2012. 


\section{CONCLUSION}

The type of the ferment (natural or commercial) did not significantly influence the physicochemical composition of cachaça, which was markedly altered by the maturation period in oak containers. However a loss of acceptability of the aged beverage produced with commercial ferment was verified, which did not occur with the cachaça from spontaneous fermentation of sugar cane juice.

\section{ACKNOWLEDGMENTS}

The authors wish to thank Fundação de Amparo à Pesquisa do Estado de São Paulo (FAPESP) for the financial support (process n.07/06979-8).

\section{REFERENCES}

AMORIM, H.V. et al. Método rápido para controle da fermentação e destilação. Saccharum/ STAB, v.2, n.4, p.3134, 1979.

AOAC. Association of Official Analytical Chemists. Official methods of analysis. 16.ed. Arlington, 1995. V.1, p.31-65.

BORRAGINI, M.C.C.B. Envelhecimento da cachaça com circulação forçada e aeração. 2009. 90f. Dissertação (Mestrado em Ciência dos Alimentos) - Faculdade de Ciências Farmacêuticas, Universidade Estadual Paulista "Júlio de Mesquita Filho”, SP. Available from: <http://www.fcfar.unesp.br/ posgraduacao/alimentosenutricao/Disertacao/2009/ Michelle_CaiadoME.pdf>. Accessed: Nov. 26, 2011.

BRASIL. Instrução Normativa n.13 (2005, 29 de junho). Regulamento técnico para fixação dos padrões de identidade e qualidade para aguardente de cana e para cachaça. Diário Oficial da União, Seção 1. 2005. 7p.

CARDOSO, D.R. et al. Influência do material do destilador na composição química das aguardentes de cana. Parte II. Quimica Nova, v.26, n.2, p.735-739, 2003. Available from: <http:// quimicanova.sbq.org.br/qn/qnol/2003/vol26n2/03.pdf>. Accessed: Nov. 26, 2011. doi: 10.1590/S0100 40422003000200004

CECCATO-ANTONINI, S.R. Microbiologia da fermentação alcoólica - a importância do monitoramento microbiológico em destilarias. São Carlos: EDUFSCAR, 2010. 105p.

DATO, M.C.F. et al. Analysis of the secondary compounds produced by Saccharomyces cerevisiae and wild yeast strains during the production of "cachaça". Brazilian Journal of Microbiology, v.36, n.1, p.70-74, 2005. Available from: <http://www.scielo.br/ scielo.php?pid=S1517-83822005000100014\&script=sci_arttext $>$. Accessed: Nov. 26, 2011. doi: 10.1590/S151783822005000100014 .

FARIA, J.B. et al. Cachaça, pisco and tequila. In: LEA, A.G.H.; PIGGOT, J.R. (Eds.). Fermented beverage production. New York: Kluwer Academic, 2003. p.335-363.

FRANCO, A.C. Redestilação da cachaça. 2008. $52 \mathrm{f}$ Dissertação (Mestrado em Nutrição) - Faculdade de Ciências Farmacêuticas, Universidade Estadual Paulista, SP. Available from: <http://www.fcfar.unesp.br/posgraduacao/ a li mentos en u t ri c a o/Dis e r t a c a $0 / 2008$ Alessandra_Franco_Completo.pdf.>. Acessed: Nov. 26, 2011.

INSTITUTO ADOLFO LUTZ. Normas Analíticas do Instituto Adolfo Lutz: métodos químicos e físicos para a análise de alimentos. São Paulo, 1985. V.1, 533p.

MacFIE, H.J.H. et al. Designs to balance the effect of order of presentation and first-order carry-over effects in hall tests. Journal of Sensory Studies, v.4, p.129-148, 1989.

MORAIS, P.B. et al. Characterization and succession of yeast populations associated with spontaneous fermentations during the production of Brazilian sugar cane. World Journal of Microbiology and Biotechnology, v.13, p.241-243, 1997. Available from: <http://www.springerlink.com/content/ w312436412302123/fulltext.pdf $>$. Accessed: Nov. 26, 2011. doi: $10.1023 / \mathrm{A}: 1018558302062$.

NOVA, M.X.V. et al. Yeast species involved in artisanal cachaça fermentation in three stills with different technological levels in Pernambuco, Brazil. Food Microbiology, v.26, p.460-466, 2009. Available from: <http://www.sciencedirect.com/science/ article/pii/S0740002009000495>. Accessed: Nov. 26, 2011. doi: 10.1016/j.fm.2009.02.005.

OLIVEIRA, E.S. et al. The influence of different yeast fermentation, composition and sensory quality of cachaça. World Journal of Microbiology and Biotechnology, v.21, p.707-715, 2005. Avaliable from: <http://www.springerlink.com/ content/kj3hk7041801n772/fulltext.pdf>. Acessed: Nov. 26, 2011. doi: 10.1007/s11274-004-4490-4.

PARAZZI, C. et al. Avaliação e caracterização dos principais compostos químicos da aguardente de cana-de-açúcar envelhecida em tonéis de carvalho (Quercus sp.). Ciência e Tecnologia de Alimentos, v.28, n.1, p.193-199, 2008. Available from: <http://www.scielo.br/pdf/cta/v28n1/27.pdf>. Accessed: Nov. 26, 2011. doi: 10.1590/S010120612008000100028.

PATARO, C. et al. Physiological characterization of yeasts isolated from traditional fermentation in a cachaça distillery. Revista de Microbiologia, v.29, p.69-73, 1998.

PATARO, C. et al. Yeast communities and genetic polymorphism of Saccharomyces cerevisiae strains associated with artisanal fermentations in Brazil. Journal of Applied Microbiology, v.88, p.24-31, 2000. Available from: < http:// on linelibrary.wiley.com/doi/ $10.1046 /$ j. 1365 2672.2000.01092.x/pdf>. Accessed: Nov. 27, 2011. doi: 10.1046/j.1365-2672.2000.01092.x

ROSA, C.A. et al. Cachaça production. In: INGLEDEW, W.M (Ed.). The alcohol textbook. Nottingham: Nottingham University, 2009. p.484-497.

SILVA, C.L.C. et al. Selection, growth, and chemo-sensory evaluation of flocculent starter culture strains of Saccharomyces cerevisiae in the large-scale production of traditional Brazilian cachaça. International Journal of Food Microbiology, v.131, p.203-210, 2009a. Available from: <http:// w w w.sciencedirect.com/ s cience / a r t icle / pi i / S0168160509001378>. Accessed: Nov. 27, 2011. doi: 10.1016/ j.ijfoodmicro.2009.02.027.

SILVA, P.H.A. et al. Avaliação cromatográfica de compostos voláteis de cachaças produzidas com leveduras de diferentes procedências. Ciência e Tecnologia de Alimentos, v.29, n.1, p.100-106, 2009b. Available from: <http://www.scielo.br/ pdf/cta/v29n1/v29n1a16.pdf>. Accessed: Nov. 27, 2011. 